\title{
Zika Virus Controversies: Epidemics as a Legacy of Mega Events?
}

\author{
Alberto Krayyem Arbex ${ }^{1,2}$, Vagner Rosa Bizarro ${ }^{3}$, Mikele Torino Paletti ${ }^{3}$, \\ Odirlei Joanir Brandt ${ }^{3}$, Ana Luísa Conceição de Jesus ${ }^{4}$, Ian Werner ${ }^{5}$, \\ Luiggi Miguez Dantas, ${ }^{6}$, Mirella Hansen de Almeida ${ }^{3,7}$ \\ ${ }^{1}$ Post Graduation in Public Health and Bioethics, Fundação Oswaldo Cruz, Rio de Janeiro, Brazil \\ ${ }^{2}$ Former Visiting Scholar, Harvard T. H. Chan School of Public Health, Boston, USA \\ ${ }^{3}$ Post Graduation in Endocrinology, IPEMED Medical School, Rio de Janeiro, Brazil \\ ${ }^{4}$ School of Medicine, Federal University of Sergipe, Aracaju, Brazil \\ ${ }^{5}$ Graduation in Chemistry, Pontifical Catholic University of Rio de Janeiro, Rio de Janeiro, Brazil \\ ${ }^{6}$ Division of Infectology, Central Air Force Hospital, Rio de Janeiro, Brazil \\ ${ }^{7}$ Division of Endocrinology, Central Air Force Hospital, Rio de Janeiro, Brazil \\ Email: albertoarbex@gmail.com
}

Received 25 March 2016; accepted 24 May 2016; published 27 May 2016

Copyright (C) 2016 by authors and Scientific Research Publishing Inc.

This work is licensed under the Creative Commons Attribution International License (CC BY). http://creativecommons.org/licenses/by/4.0/

(c) (i) Open Access

\section{Abstract}

The current knowledge of the Zika Virus epidemic clearly lacks a comprehensive understanding of its determinants and clinical outcomes. Until recently regarded as a "simple" dengue-like infection, it nowadays turned into a real challenge to Public Health around the world. The Zika Epidemic shows a quick spread, affects unprepared health systems, and presents with severe neurological complications of newborns - a concrete threat to pregnancies. This re-emerging infectious disease is a source of deep doubts and harsh debates regarding Public Health and even bioethical issues. Several doubts still remain on how to deal with the various possible transmission ways of the disease, the surge of a generation of thousands of microcephalic newborns (and questions on how to handle them within limited health systems), and severe malformations concentrated so far in Northeastern Brazil. Finally, a debate is raised about how the "Endemic State" of Brazil, deeply merged in a health care crisis for almost 40 years now, currently confronts 3 current epidemics of the arboviruses Dengue, Chikungunya and now Zika, all associated with a lack of basic sanitation. Brazil must deal with these biological threats in the context of the Rio 2016 Olympic Games, since Chikungunya has probably been brought to Brazil during the FIFA Soccer World Cup (2014) and Zika Virus spread is associated with the Soccer Confederations Cup (2013).

\section{Keywords}

Zika Virus, Epidemic, Microcephaly, Bioethics, Public Health, Guillain-Barré Syndrome, Rio 2016, 


\section{Introduction}

Zika Virus belongs to the family Flaviviridae and genus Flavivirus, an arthropod-borne virus, or simply "arbovirus" [1]. This is a descriptive term applied to hundreds of predominantly RNA viruses that are transmitted by arthropods, notably by mosquitoes. Arboviruses are often maintained in complex cycles involving vertebrates such as mammals or birds and blood-feeding vectors. Until recently, only a few arboviruses had caused clinically significant human diseases, including mosquito-borne alphaviruses such as chikungunya and flaviviruses such as dengue and West Nile. The most historically important one of these was yellow fever virus, the first recognized viral cause of deadly epidemic hemorrhagic fever [2].

\section{World Spread of Zika Virus Infection}

\subsection{First Discovery in Africa, 1947}

Zika Virus was discovered in 1947 in Uganda [3], and had until recently remained as an obscure virus confined to a narrow equatorial belt running across Africa and into Asia. From the 1960s to 1980s, human infections were found across Africa and Asia, typically accompanied by mild clinical illness.

The first isolation of the virus was made in April 1947 from the serum of a pyrexial rhesus monkey caged in the canopy of Zika Forest (zika meaning "overgrown" in the Uganda language), near the East African Virus Research Institute in Entebbe, Uganda. The isolation of what is believed to be an unrecorded virus is described. The second isolation was made from a lot of mosquito Aedes africanus taken in January 1948, in the same forest. The monkey developed a fever, and researchers isolated from its serum a transmissible agent that was first described as "Zika Virus" in 1952, named after the locality from where the isolations were made [4].

In 1952, the first human cases were detected in Uganda and the United Republic of Tanzania, in a study demonstrating the presence of neutralizing antibodies to Zika Virus in sera [5]. It was subsequently isolated from a human in Nigeria in 1954 [3] [4].

A researcher in Uganda who fell ill while working with Zika strains isolated from mosquitoes provided the first proof that Zika Virus causes human disease, in 1964 [3].

\subsection{Current Zika Epidemic in the World, 2014-2016}

From its discovery until 1983, the known geographical distribution of Zika expanded to equatorial Asia, including India, Indonesia, Malaysia and Pakistan, where the virus was detected in mosquitos. As in Africa, sporadic human cases occurred, but no outbreaks were detected and the disease in humans continued to be regarded as rare, with mild symptoms [5] [6]. Seroprevalence studies in Indonesia, Malaysia and Pakistan indicated a widespread population exposure [7].

The first large outbreak of disease caused by Zika infection was reported at the Island of Yap (Federated States of Micronesia, located at the Pacific Ocean) in 2007, as the virus moved from southeast Asia across the Pacific. Prior to this event, no outbreaks and only 14 cases of human Zika Virus disease had been documented worldwide [8]. An estimated 73\% of Yap residents over three years of age were infected with Zika Virus. The condition was characterized by rash, conjunctivitis, and arthralgia, and was initially thought to be dengue. No hospitalizations, hemorrhagic manifestations, neurological complications or deaths due to Zika Virus were [9].

During 2013 and 2014, epidemics have occurred in Polynesia, Easter Island, the Cook Islands and New Caledonia. The outbreak in French Polynesia, generating thousands of suspected infections, was intensively investigated. The results of retrospective investigations are reported to World Health Organization on 24 November 2015 and 27 January 2016. These reports indicate a possible association between Zika Virus infection and congenital malformations and severe neurological and autoimmune complications. In particular, an increase in the incidence of Zika infection towards the end of 2013 was followed by a rise in the incidence of Guillain-Barré syndrome [3].

In South America, the first reports of locally transmitted infection came from Brazil. On July 2015, exactly one year after hosting the soccer World Cup, Brazil reported an association between Zika Virus infection and 
Guillain-Barré syndrome. Three months later, on October 2015 Brazil reported an association between Zika Virus infection and microcephaly. For neither event was a causal link proved on that first moment of epidemic threat [3]. Since 2015, Brazil has been facing a public health emergency regarding the dramatic increase in the number of newborn babies with microcephaly. Epidemiological data indicate that up to Feb 2, 2016, 5079 suspected cases of microcephaly were reported in 21 Brazilian States. This incidence of microcephaly is 20 times higher than in previous years, reaching 99.7 per 100,000 livebirths, and including 76 deaths of neonates as of Jan 6, 2016 [10] [11].

On February 6, 2016, as infection moved rapidly through the geographical areas where the Aedes mosquitos are present in the Americas, World Health Organization declared that the recent association of Zika infection with clusters of microcephaly and other neurological disorders constituted a "Public Health Emergency of International Concern" [3].

The Hawaii State Department of Health has received laboratory confirmation from the United States Centers for Disease Control and Prevention of a past Zika Virus infection in a baby recently born with microcephaly in a hospital on Oahu. The mother likely had Zika infection when she was residing in Brazil in May 2015 and her newborn acquired the infection in the womb. The case could be the first one reported in the United States linking the birth defect with the virus. To date, there have been no cases of Zika Virus acquired in Hawaii. Since 2014, the department has identified six persons in the state who acquired their infection in another country [12].

Several countries outside the Americas report now infections on individuals who visited Americas and the Caribbean recently [13].

\section{Biochemical Definitions}

\subsection{Virus Strains: Different Origins}

The characterization of Zika Virus strains collected in Cambodia, Malaysia, Nigeria, Senegal, Thailand and Uganda was recently published, and allow to build phylogenetic trees and understand the changes that occurred to it. Two geographically distinct lineages of the virus, the African and the Asian ones, were identified. The phylogenetic results indicate that the Cambodian strain diverged recently from the Malaysian strain. Therefore, the recent common ancestor of the Cambodian strain had been circulating in Southeast Asia since at least the mid-1900's. These data indicate that Cambodian strain was either recently introduced or that it has been circulating in the region and remained undetected until 2010 [8].

Analysis of the epidemic from Yap Island strengthens previous epidemiological evidences that the outbreak on Yap Island originated in southeast Asia [3].

On the last few months of 2015 and 2016, researchers detected and published the sequencing of Zika Virus from amniotic fluid of fetuses with microcephaly in Brazil. After sequencing the complete genome of the Zika Virus found among Brazilian patients, phylogenetic analyses showed that the virus shares $97 \%-100 \%$ of its genomic identity with lineages isolated during an outbreak in French Polynesia in 2013 [10].

\subsection{Viral Structure}

Zika Virus is closely related to Spondweni virus. Both viruses are the only members of their clade within the mosquito-borne cluster of flaviviruses. The next closest relatives include Ilheus, Rocio, and St. Louis encephalitis viruses. Yellow fever virus is the prototype of the Flavivirus family, which also includes Dengue, Japanese encephalitis, and West Nile viruses [1].

Information regarding pathogenesis of the Zika Virus is still scarce, but mosquito-borne flaviviruses are thought to replicate initially in dendritic cells near the site of inoculation, and then spread to lymph nodes and to the bloodstream. Although flaviviral replication is thought to occur in cellular cytoplasm, a recent study suggested that Zika Virus antigens could be found in infected cell nuclei. Viral nucleic acid has been detected as late as 11 days after onset of infection. The virus was isolated from the serum of a monkey 9 days after experimental inoculation.

Zika Virus is killed by potassium permanganate, ether, and temperatures over $60^{\circ} \mathrm{C}$, but it is not effectively neutralized with $10 \%$ ethano [1].

Regarding the basic structure and the potential viral proteins of the Zika Virus, it does not differ considerably from other members of the genus Flavivirus such as the Kedougou and Spondweni viruses, belonging to the 
same group as the former while causing resembling symptoms, the first being closest to the Dengue Virus, despite no identified illness [9]. Its genome consists of a 10,794 base long single-stranded, non-segmented RNA of positive polarity which encodes three structural (C, capsid; $\mathrm{M}$, membrane and E, envelope) and seven nonstructural proteins (NS1, NS2A, NS2B, NS3, NS4A, NS4B, NS5) [10]. The 5' end has a cap 1 structure, with a methylated 2'-hydroxy group on the first ribose sugar, for cellular translation and the 3' terminus forms a loopshaped secondary structure. This subgenomic flavivirus RNA, shown in all members in this genus, leads to an inhibition of XRN1, thus resulting in an increase in stability of the cellular mRNA [11].

The Zika Virus has a diameter of about $50 \mathrm{~nm}$ and its envelope and capsid are of an icosahedral shape. There are dimmers of the envelope proteins E consisting of a receptor, a transmembrane protein and a cell-cell fusogen on each surface of the outer side with two membrane proteins $\mathrm{M}$ associated to each dimer. Right below, capsid proteins $\mathrm{C}$ surround the inner viral genome. Observations on the capsid core indicate direct contact of the RNA with the C protein [12]. Since the Zika Virus belongs to the same genus as Dengue, West Nile and Japanese encephalitis (JEV) viruses, their overall structure is quite similar. Features such as size, shape, a secondary structure at the 3' terminus instead of a poly (A) tail and in a 11,000 base long single-stranded, non-segmented positive RNA genome, encoding 5 structural and 7 nonstructural proteins are all present in members of the flavivirus genus [2]. One of the main methods of describing the evolution of this genus, thus the evolution of the $\mathrm{Zika} \mathrm{Vi-}$ rus, is by analyzing the protein sequence of its longest and most conserved protein: NS5 [14] [15]. Along with NS3, this protein is responsible for viral RNA replication and has the least rate of change, with NS3 at second [2], making both of them adequate targets for developing antiviral drugs, not only against Zika Virus, but also against all flaviviruses [15].

\section{An International Public Health Challenge}

\subsection{Health Concern among Countries}

On February 1, 2016 WHO declared the Zika Virus spread in South American and Caribbean countries a "Public Health Emergency of International Concern", or simply a "PHEIC" [16], mainly "because of what is not known” about this infection, especially regarding its association with the Guillain-Barré Syndrome, microcephaly among newborns and other neurologic defects [17] and other among newborns of pregnant women diagnosed with Zika might also be an explanation for this The quick disease spread in the Americas, along with the report of unprecedent notifications of Zika virus infections among different countries and continents, including cases reported among European and North American citizens who recently visited those countries affected by the Zika epidemic, suggest the risk of a new world health threat. Zika is the fourth epidemic that deserves such an international alarm: Ebola, Polio and H1N1 Influenza infection are the other 3 conditions that caused such a statement [18].

More than 50 countries have reported cases of Zika Virus infection until March 2016, and these numbers shall increase. The biggest hazard and concern posed by this world epidemic is the risk of microcephaly among newborns. Funds are being raised to investigate this association in affected countries, but as a newly "rediscovered" disease, answers are outnumbered by questions so far [19].

\subsection{Mega Events in Brazil: Epidemics as a Legacy?}

The idea of hosting world events such as the FIFA Soccer World Cup in 2014 and the Olympic Games in 2016 is quickly moving from intense crowd euphoria to the regrettable reality that neither Brazil's real problems of poverty and social inequality nor the economic or the environmental challenges will even minimally be faced. Recent published data on the expected legacy of the Olympic Games show that the effect of the Games will be more social segregation in Brazil and no improvement on health or physical activity of the host population [20] [21].

A concrete legacy of hosting mass events for the country is already confirmed: the spread of epidemics and the impact of health problems such as the Chikungunya Virus and the Zika Virus epidemics are directly associated with those events [22] [23]. In 2013 Zika virus probably arrived in Brazil, during the Soccer Confederations Cup, although other international events held in Rio are also associated with it, especially the Va'a World Sprint Championship canoe race [24]. The year of 2014 (World Cup) is already documented as the year in which the Chikungunya infection was firstly reported in Brazil [22]. 2015 is the date in which Zika virus infections 
were reported, along with an unprecedent increase of microcephaly and serious damages among Brazilian northeastern newborns [19] [24]. Shall this be the biological heritage of hosting mega events for the country? The economy and social aspects have proved to receive minimal benefits of hosting mega events [25] [26], since Brazil nowadays experiences the deepest economic crisis in a hundred years, since 1930 [27].

\subsubsection{Poor Sanitation and the Spread of Epidemics}

Inadequate Sanitation, defined as a lack of "the provision of facilities and services for the safe disposal of human urine and faeces" [28], is a current challenge in Brazil. Different sources suggest that between $17 \%$ and 55\% of Brazilian homes have inadequate access to basic sanitation [29] [30] with 48\% unimproved sanitation in rural areas, especially in the Northeastern and Northern regions of the country. Even in the most important urban areas, such as Brasilia, Sao Paulo and Rio de Janeiro, this problem remains unsolved [31].

These high levels of inadequate sanitation are strongly associated with the difficulty to control epidemics. [32].

No national campaign based on eradication of a vector is expected to achieve adequate success, because Brazil's degraded and impoverished urban contexts are an essential, though neglected part of the problem. Therefore, improvements in the urban environment are necessary to tackle this challenge. No such government campaigns as "Zika Zero" (an unreal, illusionary goal) and "60 million people are stronger than a mosquito" [33] (current government campaigns) show minimal effects on solving the problem, since the epidemic numbers keep increasing. The Brazilian government focuses on convincing their population that the Aedes aegypti is the single source of the problem, whilst its real reason are, in fact, centuries of neglected investments on basic sanitation of Brazil. Many epidemics out of control, along with severe—and even so increasing—social inequality, suggest a worsening of this situation in the near future and ahead [31].

Three months before the Rio 2016 Olympic Games a World Health Organization Statement recommended athletes and visitors of Rio de Janeiro to "avoid visiting impoverished and over-crowded areas (...) with no piped water and poor sanitation" [34]. This statement understands that "the risk of being bitten [by the Aedes mosquito] is higher". The local Medical Council of Rio de Janeiro recently alerted authorities of the Olympics organizing committee that public medical assistance in Rio is poor and already overcrowded. Structural "difficulties are old and well-known”, according to a counselor [63].

Public opinion ranges from the worry about risks of a global epidemic of Zika associated with the Games, according to an opinion issued this May 2016 at the Harvard Public Health Review [35], to a comment published at the "New Scientist", arguing that the risk of infection is low for visitors of the Games [36]. Either ways, poor sanitation remains as a crucial and long-term challenge in Brazil and in South America, and must be tackled urgently after decades of ineffectiveness, under the risk that other (new and old) biological hazards would spread.

\section{Brazil: Endemic State}

\subsection{Dengue}

An Endemic state of Dengue infections is a part of Brazilian's daily lifes for almost 40 years now, since the year of 1981. It is possible to state that it is part of Brazilian modern history. This harsh fact shows how the current approach is inadequate and even uneffective towards such a severe infection, which already affected (officially) more than 10 million Brazilians, and caused around 4000 deaths [37]-[39]. The real number of Dengue infections is possibly 12 times higher than this official serologic registry, meaning that more than $60 \%$ of Brazilians already could have had a Dengue infection episode; in other words, 120,000,000 cases of the disease within a few decades. Underreporting is still the rule, accounting for most cases of Dengue and other infections [40].

The history of the Dengue virus infections began in the end of the eighteenth century, when its first cases were reported in Southeast Asia and in Philadelphia, United States. Transmitted by the mosquito Aedes aegypti, which was probably brought to Brazil in slave ships, the disease is likely to have had its first outbreak in the country in 1916, in Sao Paulo. In the beginning of the past century, however, the mosquito had been eradicated after an intense campaign against the yellow fever, also transmitted by the same vector. Nevertheless, the intense urbanization and industrialization occurred during the decades of 1940 and 1950 became a new start to the propagation of the Aedes, which expanded its dissemination across the country [41].

In the last 50 years, Dengue's incidence has increased over 30 times, reaching new countries and small, rural 
cities. Every year, it is estimated that 50 million new infections occur, exposing 2.5 billion people in the world to this threat - this is the number of people who live in Dengue endemic areas. Epidemic outbreaks have been happening every 3 to 5 years in the Americas. In Brazil, the biggest epidemic happened just recently, in 2013, when 2 million new cases were reported, in a country where underreporting is the rule. Nowadays, there are four different known serotypes of the virus circulating in the country [42].

Dengue virus' infection presents with a large spectrum of symptoms. The patient may range from no symptoms to developing a serious hemorrhagic condition that frequently leads to death. In the first case, called "Classical Dengue”, the infection tends to start with a (usually high) fever, accompanied by symptoms such as headache, myalgia, arthralgia and exanthema. In the second and much more severe situation, known as "Dengue Hemorrhagic Fever” (DHF), the infection firstly begins as the Classic infection, but changes its course when the fever relieves. Spontaneous hemorrhagic manifestations than occurs, with moderate to severe thrombocytopenia, along with severe dehydration. The patient may shock if not treated correctly - this is where Dengue’s mortality rates increase [43].

However, Dengue virus is not the only disease transmitted by the mosquito Aedes aegypti.

\subsection{Chikungunya}

The Chikungunya is another virus that has the Aedes mosquito as its vector. The virus was initially isolated in Tanzania, Africa, in 1952. In recently affected areas, Chikungunya has been responsible for intense epidemics, which have infected about 38\% - 63\% of the local population. Until October 2014, 828 cases of the Chikungunya fever had been confirmed in Brazil. Among those, only 39 were from abroad. It was also verified that two different viral genotypes had entered the country, as the one found in Oiapoque, Northern Brazil (first Brazilian city where the disease was confirmed) was different from that one studied in Bahia, Northeastern Brazil [44].

Brazil's geographic shape shows how the country is susceptive and vulnerable to this new infection. As the Chikungunya Virus is transmitted by the Aedes aegypti, it already had a widely spread population of vectors able to disseminate the disease. As well as that, the existence of infected patients, in contact with those vectors, fundaments the possibility of a wide transmission across the country. The Soccer World Cup, a mega event that occurred in 2014 in 12 cities of Brazil, was a main reason of concern due to welcoming a great number of tourists from all around the world. The entrance of the Chikungunya Virus in the country probably occurred during that event. Only in 2015, 20,662 autochthonous suspicious cases of the Chikungunya fever were reported. 18,793 of those happened only in the Northeast of the country. These data show a peak increase when compared to the year before, 2014 [44].

The Chikungunya Virus, nevertheless, was not the only disease that intensely entered Brazil in this massive event. According to the Ministry of Health, many other illnesses may have entered the country in 2014, since no effective plan was made to control these risk. Hemorrhagic fevers, cholera, avian influenza A and even the Zika Virus disease were associated with the mega event. This new situation took the Health Surveillance Secretariat of the Ministry of Health by surprise and, as of February 2015, 8 months after the World Cup, an intense notification of all undetermined rash syndromes in Northeastern Brazil was demanded, after the problem was already posed [44].

\section{Clinical Features and Complications: Beyond Microcephaly}

\subsection{Clinical Features}

Zika Virus infection is mainly transmitted (but not exclusively) by the same vector of dengue and Chikungunya fevers-Aedes aegypti-which mainly explains why it has spread so widely in Brazil, after entering the country in 2014 [45]. Recent reports show that sexual transmission is a probable cause of Zika infection among mates of patients who visited endemic areas in 2015 and early 2016.

A recent study showed that the Zika Virus is present in the salivar glands of the Culex mosquito, whose presence in Brazl is 20 times more frequent than the Aedes. If this finding would be associated with the possibility of the Culex mosquito of also spreading the virus, that would pose an even greater risk to the populations of the Americas and the Caribbean.

The ongoing pandemic confirms that Zika is predominantly a mild or asymptomatic disease, with only $20 \%$ of the patients presenting clinical symptoms [46]. Some of the reported symptoms are low fever, exanthema, arth- 
ralgia, myalgia and headache (all of them also present in other viral fevers, such as Dengue and Chikungunya). This similarity of symptoms poses a challenge to the clinician.

A limited number of reported cases are available so far, and therefore until early 2016 the Brazilian Ministry of Health was using the Dengue Clinical Protocol to deal with Zika infections, which seems to be inadequate [22].

A key prospective study was published on March 2016, describing the clinical features of 88 pregnant women in Rio de Janeiro, Brazil, who had a rash within 5 days. Among them, $82 \%$ tested positive for Zika, 28\% had fever, fetal abnormalities were detected by ultrasonography in $29 \%$ of positive testers. The study confirms previous reports of the association between Zika virus infection and an elevated risk of fetal death, placental insufficiency and CNS injury [47].

On February 2016 the CDC published a Clinical Protocol indicating how to deal with the possibility of a Zika virus infection. This shall be the first guideline on the theme, which will certainly be followed by other, more precise directions, based on the new data that is being published.

\subsection{Complications}

Data from French Polynesia documented a concomitant epidemic of 73 cases of Guillain-Barré Syndrome and other neurologic conditions in a population of approximately 270,000 (around 2 cases for every 10,000 inhabitants), which represents a severe complication of Zika, since this is represents rare, complicated autoimmune CNS Syndrome.

Of greater concern is the explosive Brazilian epidemic of microcephaly, manifested by an apparent 20-fold increase in its incidence between 2014 and 2015, and that a physician at Paraiba, Dr. Adriana Melo, firstly suggested that was associated with Zika virus infections among pregnant women. Although no other flavivirus was known so far to show teratogenic effects, this microcephaly epidemic has not yet been linked to any other cause, such as increased diagnosis or reporting, increased ultrasound examinations of pregnant women, or other infectious or environmental agents. Despite the lack of definitive proof of a causal relationship, but because of the strong association found, some health authorities in afflicted regions are recommending that pregnant women take meticulous precautions to avoid mosquito bites, and even —as official statements from local, regional and national governments-to delay pregnancy [48] [49].

Microcephaly is a clinical finding and not a disease. It is defined as an occipital-frontal head circumference (OFC) smaller than expected for gestational age and gender. Since the growth of the cranium depends on the forces of an expanding brain, microcephaly is an indicator of an undersized brain. Whilst the measurement of OFC is a trusted assessment of intracranial brain volume, controversy exists about the lower limit for this measurement as well as for the need of ethnically controlled data. Furthermore, the clinical implications of an undersized brain are far more complex to establish [50].

Since November 2015, there has been a dramatic increase in reported numbers of microcephaly in Northeast Brazil. The public health implications could be enormous. Whilst clinical and epidemiological studies are necessary to establish the extent of the problem, there is an understandable pressure from the Brazilian population, particularly women at reproductive age, for quick answers.

Cases have been diagnosed in nine Brazilian states so far. By 28 November 2015, 646 cases had been reported in Pernambuco state (Northeastern Brazil) alone. Although reports have circulated regarding the declaration of a state of national health emergency, there is no information on the imaging and clinical findings of affected cases. Authorities are considering different causal theories for the "microcephaly outbreak", among which the most important is the association with the emergence of Zika virus epidemic in Northeastern Brazil, the first case of which was detected in May 2015 [51] [52].

Intrauterine infections affecting the brain are relatively rare; cytomegalovirus, toxoplasmosis, herpes virus, syphilis and rubella are well known vectors of fetal disease. Among the Flaviviruses there have been only isolated reports linking West Nile encephalitis to fetal brain insults [53].

In the meantime, in Paraiba state, Northeastern Brazil, six children diagnosed with Zika virus were born to mothers who were apparently symptomatic during pregnancy, all of them with neonatal Head Circumference below the $10^{\text {th }}$ percentile. Fetal neurosonograms showed two cases with cerebellar involvement and three with brain calcifications. One had severe arthrogryposis [28].

The presence of calcifications was suggestive of an intrauterine infection; but severe damage of the cerebellum, brainstem and thalami is rarely associated with intrauterine infection. 
There are two cases-report of “Congenital Zika Virus” reported at the State of Paraíba, Northeastern Brazil, showing some similarities to Citomegalovirus cases, but with a more severe and destructive pattern. These lack the nodules characteristic of toxoplasmosis. Interestingly, the reported case of fetal West Nile virus infection has similar characteristics [11].

In the first case, anomalies were limited to the brain and included brain atrophy with coarse calcifications involving the white matter of the frontal lobes, including the caudate, lentostriatal vessels and cerebellum. Corpus callosal and vermian dysgenesis and enlarged cisterna magna were observed [28].

The transabdominal axial ultrasound image showed cerebral calcifications with failure of visualization of a normal vermis. Calcifications were also present in the brain parenchyma. Transvaginal sagittal image showed dysgenesis of the corpus callosum and vermis. Coronal plane showed a wide interhemispheric fissure due to brain atrophy and bilateral parenchymatic coarse calcifications [28].

In the second case, the cerebral hemispheres were markedly asymmetric with severe unilateral ventriculomegaly, displacement of the midline, thinning of the parenchyma on the dilated side, failure to visualize the corpus callosum and almost complete disappearance or failure to develop the thalami. The pons and brainstem were thin and continuous with a non-homogeneous small mass at the position of the basal ganglia. Brain calcifications were more subtle than in case one and located around the lateral ventricles and fourth ventricle. Both eyes had cataracts and intraocular calcifications, and one eye was smaller than the other [28].

This case shows severe fetal brain injury associated with Zika virus infection with vertical transmission. Recently, the virus was found in amniotic fluid of two fetuses that were found to have microcephaly, which was consistent with intrauterine transmission of the virus [54] [55].

Described cases are similar to the case presented here and were characterized by severely affected CNS (which suggests a strong neurotropism of the virus) and gross intrauterine growth retardation. Calcifications in the placenta and a low placental-fetal weight ratio, indicate potential damage to the placenta by the virus. Among the few reports of teratogenic effects of flaviviruses, investigators described the brain and eyes as the main targets [12].

As with other intrauterine infections, it is possible that the reported cases of microcephaly represent only the more severely affected children and that newborns with less severe disease, affecting not only the brain but also other organs, have not yet been diagnosed [28].

A possible explanation for this neurotropism of the current strain of Zika Virus Epidemic is showed by some recent studies that confirm in vitro that Zika Virus infection in human neural progenitor cells dysregulates cellcycle progression, resulting in attenuated neural growth [56]. Zika Virus reduces the viability of neural stem cells and severely affects human neurogenesis [57].

If patients diagnosed in other states are found to be seropositive for Zika virus, this represents a severe health threat that needs to be controlled expeditiously. The Brazilian authorities reacted rapidly by declaring a state of national health emergency. As there is no known medical treatment for this disease, a serious attempt will be needed to eradicate the mosquito and prevent the spread of the disease to other Brazilian states and across the border [22] [30].

\section{Bioethical Debate}

Important bioethical questions are being raised by the Zika Virus epidemic, regarding available public policies and interventions towards its control. Their proportionality, and the rationale for justified interventions, ought to be discussed before application among societies; otherwise, measures could be introduced without individual consent, conflicting with personal rights [58].

The Right to Health is an inclusive right that has specific implications on adequate sanitation and reproductive health [59]. The 2011 WHO Health Convention states that "maternity is a social function", and therefore women should have the right to freely and responsibly decide on their pregnancies. States should also, according to the WHO's recent statements on Health Rights, ensure adequate pre-natal and post-natal health care. These rights are especially important when a mother is infected by Zika and needs specific care, before or during pregnancy, and after carriage [60].

The WHO is also very clear on questioning frequent laws that restrict women's right to abortion, stating that these "must be eliminated", because they directly infringe women's dignity and their autonomy to decide whether they should keep up with pregnancy or not. When it comes to pregnancies at risk, and possibly unviable fetuses, such as frequently happens among mothers infected by Zika and whose babies are affected, this right to 
decide becomes imperative. Therefore, the main debate regards the right of pregnant women to interrupt pregnancy, when the fetus becomes severely affected by microcephaly or other brain or tissue damages [61].

The currently mostly affected countries by the Zika epidemic, most of them located in Latin America, also share a common restriction: their laws forbid or restrict the possibility of abortion, frequently based on the bioethical principle of the "sanctity of life". These laws impair the freedom of choice of pregnant women. More important, the official orientation from health ministries in Latin America has been to "delay pregnancy" while the Zika Epidemic still remains in high rates, which brings along many important outcomes regarding birth rates, women's reproductive rights, inadequate health systems and several other personal rights affected by such a specific State policy [62]. Some authors even suggest that this epidemic might bring along, as a result, a boost on debates among Latin American Governments and society, towards improving rights of vulnerable populations and raise a broader debate on abortion and women's sexual rights in Latin America [15].

\section{Prospects for Research}

Many key points remain unsolved regarding this reemerging disease, and raise priority prospects for research:

- Adequate sanitation is a current challenge in Brazil and in South America. Only around 50\% of Brazilian homes have adequate sanitation throughout the country;

- The biological legacy of hosting mega events and the increased risk of spreading world biological hazards to human health;

- The similarities among the Polinesian and the Brazilian epidemics of Zika, and their association with the Guillain-Barre Syndrome that happened in Polinesia, happened in Polinesia during the year of 2014;

- The risk of a new epidemic of microcephaly in Colombia, where the Zika epidemic numbers are on the way to reach the Brazilian levels;

- To better assess the efficacy and the risks of proposed ways of vector control, such as social participation, genetically modified mosquitoes, Wolbachia infection in mosquitoes, irradiation, and the environmental risks associated with a possible indiscriminate use of environmental agents to kill the mosquitoes;

- Possible effective drugs to treat Zika infection in pregnant women and prevent CNS lesions of the newborn, especially during the first 3 months of pregnancy;

- To reorganize the politics towards infectious diseases in underdeveloped countries, putting the challenges of poverty and lack of adequate sanitation among priorities, together with current privileged cardiovascular diseases;

- To discuss bioethical issues raised by the severe damages to newborns, such as the right of pregnant women to decide about their pregnancy outcomes.

\section{Conclusions}

Adequate sanitation should be discussed as a possible more important target than simply combating the vector (Aedes aegypti), since long-term public policies are necessary to tackle arboviroses such as Zika, Chikungunya and Dengue epidemics, and possible future hazards.

The legacy of the Rio 2016 Olympic Games is increasingly being associated with current ineffective public policies on dealing with epidemics. These three viral infections are major hazards to worldwide health, having affected so far more than half the Brazilian population, with a true potential of spread to other countries and continents.

Many doubts and controversies still remain about the prevention, epidemiology, outcomes and consequences to populations, since these epidemics turned out to be a new challenge to public health worldwide. A fast building and sharing of the available knowledge about this disease are one of the key weapons towards controlling it as quick as possible.

Efforts should be made to understand and better organize the health systems of the Latin American countries affected by this epidemic, since they are so far not prepared to handle with Zika and its life-long clinical consequences. If the goal is really to eradicate these (re)emerging challenges, Public Health policies in these countries have now to reset priorities.

\section{Acknowledgements}

The authors would like to thank the FIOCRUZ entire team of researchers, for their unlimited efforts to better 
understand these and other key current threats to health among Latin American populations. The relevance of this institution for the health of Americas and the Caribbean has again been confirmed, in this moment of challenges and doubts about the future of Latin American Public Health.

\section{References}

[1] Fauci, A.S. and Morens, D.M. (2016) Zika Virus in the Americas-Yet Another Arbovirus Threat. New England Journal of Medicine, 374, 601-604. http://dx.doi.org/10.1056/NEJMp1600297

[2] Smithburn, K.C. (1952) Neutralizing Antibodies against Certain Recently Isolated Viruses in the Sera of Human Beings Residing in East Africa. Journal of Immunology, 69, 223-234.

[3] Disk, G.W.A., Kitchen, S.F. and Haddow, A.J. (1952) Communications 509-Zika Virus (I). Isolations and Serological Specifity. Transactions of the Royal Society of Tropical Medicine and Hygiene, 46, 34.

[4] MacNamara, F.N. (1954) Zika Virus: A Report on Three Cases of Human Infection during an Epidemic of Jaundice in Nigeria. Transactions of the Royal Society of Tropical Medicine and Hygiene, 48, 139-145. http://dx.doi.org/10.1016/0035-9203(54)90006-1

[5] Kindhauser, M.K., Allen, T., Frank, V., Santhana, R. and Dye, C. (2016) Zika: The Origin and Spread of a Mosquito-Borne Virus. Bulletin of the World Health Organization. http://dx.doi.org/10.2471/BLT.16.171082

[6] Olson, J.G., Ksiazek, T.G., Suhandiman and Triwibowo (1981) Zika Virus, a Cause of Fever in Central Java, Indonesia. Transactions of the Royal Society of Tropical Medicine and Hygiene, 75, 389-393. http://dx.doi.org/10.1016/0035-9203(81)90100-0

[7] Darwish, M.A., Hoogstraal, H., Roberts, T.J., Ahmed, I.P. and Omar, F. (1983) A Sero-Epidemiological Survey for Certain Arboviruses (Togaviridae) in Pakistan. Transactions of the Royal Society of Tropical Medicine and Hygiene, 77, 442-445. http://dx.doi.org/10.1016/0035-9203(83)90106-2

[8] Haddow, A.D., Schuh, A.J., Yasuda, C.Y., Kasper, M.R., Heang, V. and Huy, R. (2012) Genetic Characterization of Zika Virus Strains: Geographic Expansion of the Asian Lineage. PLoS Neglected Tropical Diseases, 6, e1477. http://dx.doi.org/10.1371/journal.pntd.0001477

[9] Kuno, G. and Chang, G.J. (2007) Full-Length Sequencing and Genomic Characterization of Bagaza, Kedougou, and Zika Viruses. Archives of Virology, 152, 687-696. http://dx.doi.org/10.1007/s00705-006-0903-z

[10] Blok, J. and Gibbs, A.J. (2005) Molecular Systematics of the Flaviviruses and Their Relatives. Molecular Basis of Virus Evolution, 270.

[11] Roby, J.A., Pijlman, G.P., Wilusz, J. and Khromykh, A.A. (2014) Noncoding Subgenomic Flavivirus RNA: Multiple Functions in West Nile Virus Pathogenesis and Modulation of Host Responses. Viruses, 6, 404-427. http://dx.doi.org/10.3390/v6020404

[12] Jones, C.T., Ma, L., Burgner, J.W., Groesch, T.D., Post, C.B. and Kuhn, R.J. (2003) Flavivirus Capsid Is a Dimeric Alpha-Helical Protein. Journal of Virology, 77, 7143-7149. http://dx.doi.org/10.1128/JVI.77.12.7143-7149.2003

[13] Maria, A.T., Maquart, M., Makinson, A., Flusin, O., Segondy, M., Leparc-Goffart, I., Le Moing, V. and Foulongne, V. (2016) Zika Virus Infections in Three Travellers Returning from South America and the Caribbean Respectively, to Montpellier, France, December 2015 to January 2016. Eurosurveillance, 21, 30131. http://dx.doi.org/10.2807/1560-7917.ES.2016.21.6.30131

[14] Zhao, Y., Soh, T.S., Zheng, J., Chan, K.W.K., Phoo, W.W., Lee, C.C., Shi, P.Y., et al. (2015) A Crystal Structure of the Dengue Virus NS5 Protein Reveals a Novel Inter-Domain Interface Essential for Protein Flexibility and Virus Replication. PLoS Pathogens, 11, e1004682. http://dx.doi.org/10.1371/journal.ppat.1004682

[15] Le Breton, M., Meyniel-Schicklin, L., Deloire, A., Coutard, B., Canard, B., De Lamballerie, X., Andre, P., RabourdinCombe, C., Lotteau, V. and Davoust, N. (2011) Flavivirus NS3 and NS5 Proteins Interaction Network: A HighThroughput Yeast Two-Hybrid Screen. BMC Microbiology, 11, 1. http://dx.doi.org/10.1186/1471-2180-11-234

[16] World Health Organization (2016) WHO Statement on the First Meeting of the International Health Regulations (2005) (IHR 2005) Emergency Committee on Zika Virus and Observed Increase in Neurological Disorders and Neonatal Malformations. Saudi Medical Journal, 37, 332-333.

[17] Heymann, D.L., Hodgson, A., Freedman, D.O., Staples, J.E., Althabe, F., Baruah, K., Menon, K.U., et al. (2016) Zika Virus and Microcephaly: Why Is This Situation a PHEIC? The Lancet, 387, 719-721. http://dx.doi.org/10.1016/S0140-6736(16)00320-2

[18] Villarreal, P.A. (2016) Zika Virus as a Public Health Emergency of International Concern: Insights from Previous Cases. Groningen Global Health Law.

https://ghlgblog.wordpress.com/2016/02/08/zika-virus-as-a-public-health-emergency-of-international-concern-insightsfrom-previous-cases/\#more-592 
[19] Musso, D., Baud, D. and Gubler, D.J. (2016) Zika Virus: What Do We Know? Clinical Microbiology and Infection, in press. http://dx.doi.org/10.1016/j.cmi.2016.03.032

[20] Bartelt, D.D. (2015) Kehrseite der Medaille-Sportgroßereignisse in Brasilien zwischen Fehlplanung, Spekulation und dem Recht auf Stadt. Band 39, Demokratie. Heinrich Böll Stiftung. https://www.boell.de/sites/default/files/20151116 kehrseite-der-medaille.pdf

[21] Bizarro, V.R., Lucchese, T.A., Breis, A.M., Rucker, K., Fernandes, M.S.A., Paletti, M.T., de Jesus, A.L.C., Pereira, R.C.M., Rocha, D.R.T.W. and Arbex, A.K. (2016) Health, Physical Activity and the Rio de Janeiro 2016 Olympic Games: Legacy or Fallacy? Health, 8, 9-17. http://dx.doi.org/10.4236/health.2016.81002

[22] Wilson, M.E., Chen, L.H., Han, P.V., Keystone, J.S., Cramer, J.P., Segurado, A., Hale, D., Jensenius, M., Schwartz, E., von Sonnenburg, F. and Leder, K. (2014) Illness in Travelers Returned from Brazil: The GeoSentinel Experience and Implications for the 2014 FIFA World Cup and the 2016 Summer Olympics. Clinical Infectious Diseases, 58, 13471356. http://dx.doi.org/10.1093/cid/ciu122

[23] Massad, E., Wilder-Smith, A., Ximenes, R., Amaku, M., Lopez, L.F., Coutinho, F.A.B., Coelho, G.E., Silva Jr., J.B.D., Struchiner, C.J. and Burattini, M.N. (2014) Risk of Symptomatic Dengue for Foreign Visitors to the 2014 FIFA World Cup in Brazil. Memórias do Instituto Oswaldo Cruz, 109, 394-397. http://dx.doi.org/10.1590/0074-0276140133

[24] Corsica, F. (2015) Zika Virus Transmission from French Polynesia to Brazil. Emerging Infectious Diseases, 21, 18871889. http://dx.doi.org/10.3201/eid2110.151125

[25] Faria, N.R. et al. (2016) Zika Virus in the Americas: Early Epidemiological and Genetic Findings. Science, 352, 345-349. http://dx.doi.org/10.1126/science.aaf5036

[26] Preuss, H. and Schütte, N. (2016) Structures of an Economic Impact: The Case of the FIFA Football World Cup 2014 in Brazil. 7th International Sport Business Symposium, Lillehammer University College, 16 February 2016, 40.

[27] IBGE. Brazilian Gross National Product 2015. http://www.ibge.gov.br/home/estatistica/pesquisas/anos anteriores 2015.shtm

[28] World Health Organization (WHO). Health Topics: Sanitation. http://www.who.int/topics/sanitation/en/

[29] WHO/UNICEF. Joint Monitoring Programme (JMP) for Water Supply and Sanitation. http://www.wssinfo.org/documents/?tx displaycontroller[type]=country files

[30] Institute Trata Brasil. Sanitation in Brazil. http://www.tratabrasil.org.br/saneamento-no-brasil

[31] Forbes Magazine. The Next Battle for Brazil: Public Sanitation. http://www.forbes.com/sites/arthurmachado/2015/01/05/the-next-battle-for-brazil-public-sanitation/\#6bd47b2e3a03

[32] Pedley, S. and Pond, K. (2003) Emerging Issues in Water and Infectious Disease. World Health Organization.

[33] Brazilian Ministry of Education: National Campaign for the Prevention against Aedes aegypti. http://zikazero.mec.gov.br/

[34] World Health Organization (WHO). Zika Virus and the Olympic and Paralympic Games Rio 2016. WHO Statement, 12 May 2016, Media Centre. http://www.who.int/mediacentre/news/statements/2016/zika-olympics/en/

[35] Attaran, A. (2016) Off the Podium: Why Public Health Concerns for Global Spread of Zika Virus Means That Rio de Janeiro’s 2016 Olympic Games Must Not Proceed. Special Commentary-Zika Virus and Public Health Concerns, Volume 8, May 2016. http://harvardpublichealthreview.org/vol/8-special-commentary/

[36] Siegel, M. (2016) Cancel the Olympic Games in Brazil Because of Zika? No Way. New Scientist, Published on 18 May 2016.

https://www.newscientist.com/article/2088612-cancel-the-olympic-games-in-brazil-because-of-zika-no-way/

[37] Fares, R.C., Souza, K.P., Añez, G. and Rios, M. (2015) Epidemiological Scenario of Dengue in Brazil. BioMed Research International, 2015, Article ID: 321873. http://dx.doi.org/10.1155/2015/321873

[38] Paul, B. and Tham, W.L. (2016) Controlling Dengue: Effectiveness of Biological Control and Vaccine in Reducing the Prevalence of Dengue Infection in Endemic Areas. Health, 8, 64-74. http://dx.doi.org/10.4236/health.2016.81008

[39] Teixeira, M.G., Costa, M.D.C.N., Barreto, F. and Barreto, M.L. (2009) Dengue: Twenty-Five Years Since Reemergence in Brazil. Cadernos de Saúde Pública, 25, S7-S18. http://dx.doi.org/10.1590/S0102-311X2009001300002

[40] Silva, M.M.O., Rodrigues, M.S., Paploski, I.A.D., Kikuti, M., Kasper, A.M., Cruz, J.S., et al. (2016) Accuracy of Dengue Reporting by National Surveillance System, Brazil. Accuracy of Dengue Reporting by National Surveillance System, Brazil, Emerging Infectious Diseases, 22, 336-339. http://dx.doi.org/10.3201/eid2202.150495

[41] Government of Rio De Janeiro. Rio against Dengue: The History of Dengue in the World. http://www.saude.rj.gov.br/programas-e-acoes/84-acoes/130-rio-contra-a-dengue-a-historia-da-dengue-no-mundo.html

[42] Brazilian Ministry of Health, Secretary of Health Vigilance, Department of Transmissible Diseases Control (2016) Dengue: Diagnosis and Clinical Guidelines: Adults and Children. Ministry of Health, Brasília. 
[43] Brazilian Ministry of Health, National Health Foundation (2002) Dengue: Diagnóstico e manejo clínico. Ministério da Saúde, Brasília.

[44] Brazilian Ministry of Health, National Health Foundation (2002) Dengue: Aspectos epidemiológicos, diagnóstico e tratamento. Ministério da Saúde, Brasília.

[45] Brazilian Ministry of Health, Secretaria de Vigilância em Saúde (2015) Febre pelo vírus Zika: Uma revisão narrativa sobre a doença. Ministério da Saúde.

[46] Brazilian Ministry of Health, Secretaria de Atenção à Saúde (2015) Protocolo de atenção à saúde e resposta à ocorrência de microcefalia relacionada à infecção pelo vírus Zika. Ministério da Saúde, Brasília.

[47] Brasil, P., Pereira Jr., J.P., Raja Gabaglia, C., Damasceno, L., Wakimoto, M., Ribeiro Nogueira, R.M., Carvalho de Sequeira, P., Machado Siqueira, A., Abreu de Carvalho, L.M., Cotrim da Cunha, D., Calvet, G.A., et al. (2016) Zika Virus Infection in Pregnant Women in Rio de Janeiro-Preliminary Report. The New England Journal of Medicine. http://dx.doi.org/10.1056/NEJMoa1602412

[48] Marcondes, C.B. and Ximenes, M.F. (2015) Zika Virus in Brazil and the Danger of Infestation by Aedes (Stegomyia) Mosquitoes. Revista da Sociedade Brasileira de Medicina Tropical, 49, 4-10.

[49] Fauci, A.S. and Morens, D.M. (2016) Zika Virus in the Americas-Yet Another Arbovirus Threat. New England Journal of Medicine, 374, 601-604. http://dx.doi.org/10.1056/NEJMp1600297

[50] Soares de Araújo, J.S., Regis, C.T., Gomes, R.G.S., Tavares, T.R., Rocha dos Santos, C., Assunção, P.M., et al. (2016) Microcephaly in Northeast Brazil: A Review of 16208 Births between 2012 and 2015. Bulletin of the World Health Organization.

[51] Campos, G.S., Bandeira, A.C. and Sardi, S.I. (2015) Zika Virus Outbreak, Bahia, Brazil. Emerging Infectious Diseases, 21, 1885-1886. http://dx.doi.org/10.3201/eid2110.150847

[52] Melo, A.S.O., Malinger, G., Ximenes, R., Szejnfeld, P.O., Sampaio, S.A. and Bispo de Filippis, A.M.B. (2016) Zika Virus Intrauterine Infection Causes Fetal Brain Abnormality and Microcephaly: Tip of the Iceberg? Ultrasound in $\mathrm{Ob}$ stetrics and Gynecology, 47, 6-7. http://dx.doi.org/10.1002/uog.15831

[53] Centers for Disease Control and Prevention (CDC) (2002) Intrauterine West Nile Virus Infection-New York, 2002. Morbidity and Mortality Weekly Report (MMWR), 51, 1135-1136.

[54] Brazilian Ministry of Health, Secretaria de Vigilância em Saúde (2016) Monitoramento dos casos de dengue, febre de chikungunya e febre pelo vírus Zika até a Semana Epidemiológica 3. Ministério da Saúde.

[55] Mlakar, J., Korva, M., Tul, N., Popović, M., Poljšak-Prijatelj, M., Mraz, J., Kolenc, M., Rus, K.R., Vipotnik, T.V., Vodušek, V.F., Vizjak, A., Pižem, J., Petrovec, M. and Županc, T.A. (2016) Zika Virus Associated with Microcephaly. The New England Journal of Medicine, 374, 951-958. http://dx.doi.org/10.1056/NEJMoa1600651

[56] Tang, H., Hammack, C., Ogden, S.C., Wen, Z., Qian, X., Li, Y., Yao, B., Shin, J., Zhang, F., Lee, E.M., Christian, K.M., et al. (2016) Zika Virus Infects Human Cortical Neural Progenitors and Attenuates Their Growth. Cell Stem Cell, 18, 587-590. http://dx.doi.org/10.1016/j.stem.2016.02.016

[57] Garcez, P.P., Loiola, E.C., da Costa, R.F.M., Higa, L., Trindade, P., Delvecchio, R., et al. (2016) Zika Virus Impairs Growth in Human Neurospheres and Brain Organoids. Science, 352, 816-818. http://dx.doi.org/10.1126/science.aaf6116

[58] Nuffield Council on Bioethics. Briefing Note. Zika: Ethical Considerations, 2016. http://nuffieldbioethics.org/news/2016/zika-ethical-considerations/

[59] United Nations Human Rights: Toolkit on the Right to Health. http://www.ohchr.org/EN/Issues/ESCR/Pages/Health.aspx

[60] United Nations General Assembly: Sixty-Sixth Session. Right of Everyone to the Enjoyment of the Highest Attainable Standard of Physical and Mental Health. https://documents-dds-ny.un.org/doc/UNDOC/GEN/N11/443/58/PDF/N1144358.pdf?OpenElement

[61] Rubella Led to the Legalization of Abortion in the United Kingdom. Will Zika do the Same in Brazil? Interview with Ilana Lowy http://epoca.globo.com/vida/noticia/2016/02/rubeola-levou-legalizacao-do-aborto-no-reino-unido-o-zika-fara-o-mesmo -no-brasil.html

[62] United Nations Human Rights: Upholding Women’s Human Rights Essential to Zika Response. http://www.ohchr.org/EN/NewsEvents/Pages/DisplayNews.aspx?NewsID=17014\&LangID=E

[63] Regional Council of Medicine of Rio de Janeiro: Plenary Session. Medical Assistance during the Olympic Games in Rio de Janeiro, Rio 2016. (In Portuguese) http://www.cremerj.org.br/informes/exibe/3148 